\title{
Sulfur stable isotope indicators of residency in estuarine fish
}

\author{
Brian Frya,* and Matthew M. Chumchal ${ }^{b}$ \\ a Department of Oceanography and Coastal Sciences, Louisiana State University, Baton Rouge, Louisiana \\ b Biology Department, Texas Christian University, Fort Worth, Texas
}

\begin{abstract}
Estuarine fish may remain as residents in areas with favorable conditions for feeding and refuge, but become mobile and transient where conditions are less favorable. We developed a new approach involving sulfur stable isotope $\left(\delta^{34} \mathrm{~S}\right)$ distributions in fish muscle tissue to track residents and transients across estuarine salinity zones. Salinity tracking was based on $\delta^{34} \mathrm{~S}$ contrasts between freshwater and marine waters. This 5 -yr study of two Louisiana estuaries showed that riverine and upper-estuarine fish consistently had low $\delta^{34} \mathrm{~S}$ values $(-5 \%$ to $+5 \%$ o) in contrast to fish from the lower, more marine portion of estuaries that had higher $\delta^{34} \mathrm{~S}$ values $(11-17 \%)$. Residents were identified using tests of normality within community-level $\delta^{34} \mathrm{~S}$ distributions, and conceptually were considered animals permanently residing at the sampling station but also any animals present from nearby areas with similar salinities. Transients had $\delta^{34} \mathrm{~S}$ values atypical of both the location of capture and the local salinity regime. Results showed good resolution of fish movement at small $0.1-4-\mathrm{km}$ scales for low-salinity $(<2)$ upper-estuary stations, and good detection of long-range migrants from the upper estuary into the lower estuary at a coarser spatial scale of $10-30 \mathrm{~km}$. On an average basis, $2 / 3$ of the estuarine fish fauna was resident and $1 / 3$ transient. Transients were a minority in most species but commonly included small as well as large fish. This novel $\delta^{34} \mathrm{~S}$ approach may be a general technique for evaluating fish residency and movement across salinity zones in estuaries.
\end{abstract}

Station and habitat evaluations play an important role in conservation and restoration decisions. In estuaries with a typical mix of marsh and open water areas spread over a freshwater to marine salinity gradient of 0 to 35 , it is often unclear which sites and habitats are most important for fish productivity and biodiversity. Both refuge and feeding opportunities are aspects of estuarine habitats and stations important to fish (Boesch and Turner 1984), and higher fish abundances are often taken as evidence that sites are important or essential habitat (Minello et al. 2003). Further concerns center around how habitats support growth or decrease predation risk, but these aspects are harder to measure and evaluate (Beck et al. 2001). A more recent approach to habitat evaluation is to use chemical markers such as stable isotopes and trace metals to determine which habitats have relatively high importance for fish, especially habitats that have important nursery or productivity functions (Thorrold et al. 2002; Wissel and Fry 2005). Residency is potentially an additional way to assess habitat quality, with low residency and high transience likely indicating suboptimal habitats (Hoffman et al. 2007). The advantages residents may have include better avoiding local predation and better accessing local nutritious foods. The chemical marker approach can be strong for studying residency (Fry and Ewel 2003), and identifying stations where fish isotope chemistry indicates residency can help show which estuarine stations are relatively favorable as measured by the fish themselves (Fry 2002).

This study focuses on sulfur stable isotopes as chemical markers for fish residency within salinity zones. The conceptualization of residency used in this paper is broader than the traditional idea that resident fish are those

\footnotetext{
*Corresponding author: bfry@1su.edu
}

permanently inhabiting a specific geographical location. The salinity-based concept of fish residency used here means that residents may be moving between multiple nearby locations as long as these locations have similar salinity, i.e., fish are resident within a broader area or movable salinity zone centered on the site of collection, rather than resident just at that collection site. In contrast to residents, transients are fish from other salinity zones that have significantly different sulfur isotope values. The sulfur isotope values measured in fish muscle tissue reflect long-term integrated diet accumulated over several weeks and months (Hesslein et al. 1993; Barnes and Jennings 2007), so that the contrast between residents and transients is based on longer-term average habitat use rather than on short-term daily fish behavior. Modeling isotope turnover following changes in habitat and diet indicates that time integration of isotope signals is usually on the order of the previous few months (Buchheister and Latour 2010), so that our summer collections mostly measured fish residency averaged over the spring-to-summer period.

The distribution of sulfur isotopes in estuaries is determined mostly by the salinity gradient, with salinity being a strong underlying axis of differentiation for many estuarine processes and habitats. The salts in seawater include abundant sulfate at a concentration near $28 \mathrm{mmol} \mathrm{L} \mathrm{L}^{-1}$ and a high sulfur isotope $\left(\delta^{34} \mathrm{~S}\right)$ value of $21 \%$ o (Rees et al. 1978). Mixing of salt and sulfate with freshwaters dilutes this sulfate signal only very gradually because sulfate in freshwaters is typically $100-1000 \times$ less abundant than in seawater. In the Mississippi River, which provides most freshwater in our study area, sulfate concentrations are 0.3-0.5 $\mathrm{mmol} \mathrm{L}^{-1}$ (Bryan et al. 1992) and sulfate has a low $\delta^{34} \mathrm{~S}$ value averaging near $-2 \%$ (B. Fry unpubl.). Mixing of freshwater and marine sulfate 
leads to a zone of rapid $\delta^{34} \mathrm{~S}$ increase at lower salinities and high constant $\delta^{34} \mathrm{~S}$ values when salinities exceed 1-5. The change or gradient in sulfur isotope values is thus strong at low salinities but weak at high salinities, with the strong isotope gradients in the upper estuary allowing more detailed studies of fish movement at higher spatial resolution. The scale of spatial resolution for fish movement is less nearer the ocean mouth of estuaries, where $\delta^{34} \mathrm{~S}$ values begin to stabilize in broad salinity zones. Although these shifting scales of detectable fish movement may seem complications, in practice strong and useful isotope-based distinctions between residents and transients were observed in all collections from freshwater to nearly full-strength seawater. In particular, the $\mathrm{S}$ isotope approach was useful for identifying long-range transients that were common in almost all collections.

The preceding ideas about $\mathrm{S}$ isotope changes in estuaries are based on the inorganic sulfate distributions, but some further isotope fractionations are also important in food webs leading to fish. The synthesis of organic sulfur in plants proceeds with little fractionation and plants typically have high $\delta^{34} \mathrm{~S}$ values near those of sulfate (Trust and Fry 1992). However, there are larger fractionations in the production of sulfides in benthic sediments, and entry of sulfides into benthic food webs leads to lower faunal $\delta^{34} \mathrm{~S}$ values (Fry 2008; Croisetiere et al. 2009). These food web fractionations proved important in this study, but showed a consistent pattern across the salinity gradient so that $\delta^{34} \mathrm{~S}$ could still be used to track fish movement within salinity zones.

The goals of this study were to test whether fish $\delta^{34} \mathrm{~S}$ measurements would record the salinity history of a fish and whether this history could be used in studies of residency. Logistics have previously dictated that single studies usually consider a few individuals of one species for detailed studies of fish movement and residency. This study took a community approach that simultaneously encompassed 50 fish species for broad-scale patterns of movement within salinity zones. The study was done over $5 \mathrm{yr}$ in two Louisiana estuaries and involved about 3550 measurements of fish muscle ${ }^{34} \mathrm{~S}$. Large-scale diversions of Mississippi River water into the upper reaches of both estuaries provided an opportunity to test effects of salinity manipulations on fish residency. Our null hypothesis was that fish residency was constant and did not change across species, times, and locations, and remained unchanged in areas influenced by diversions. We did not conduct corroborative tagging studies in parallel with our isotope work, but found many observations that indicated the $\delta^{34} \mathrm{~S}$ results were consistent with previous studies of fish movement in estuaries, while giving several new results and a broad cross-species overview.

\section{Study area}

We sampled fish at 21 locations in two adjacent estuaries of coastal Louisiana during a 5-yr period, 2003-2007. Locations included 14 stations in Barataria Bay estuary, 6 stations in nearby Breton Sound estuary, and 1 station in the Mississippi River (Fig. 1). These stations were all within the Mississippi River deltaic plain, and the estuaries were formed over the last several thousand years by overbank flooding and sediment deposition from the Mississippi River. In the last $100 \mathrm{yr}$, an extensive set of levees has been constructed along the Mississippi River, isolating these estuaries from the river. But starting in 1991 in Upper Breton Sound, the U.S. Army Corps of Engineers has constructed large, multi-gate structures in the levee system to reintroduce or divert Mississippi River water back into local estuaries. River water flows through the diversion structures into a series of lakes and canals in upper estuaries and exerts many effects on local biology (Day et al. 2009). For example, dense communities of submerged aquatic vegetation (SAV) develop in areas of strong river input (Colon-Gaud et al. 2004; Rozas et al. 2005). We sampled fish at six upper-estuary stations in Breton Sound during 2004 and 2005 to assess long-term (> $13 \mathrm{yr}$ ) effects on fish community residency downstream of the Caernarvon diversion. All sampling areas in Breton Sound were in the low-salinity $(<2)$ area affected by the Caernarvon diversion. We sampled more extensively in nearby Barataria Bay, where a second major diversion at Davis Pond has come online starting at a low level in 2004 and at a much higher level after Hurricane Katrina in the fall of 2005. River water entering at Davis Pond proceeds through a large cypress swamp and holding pond before entering the northern Lake Cataouatche area, the main river-affected area in upper Barataria Bay sampled in this study. Both the Caernarvon and Davis Pond diversions are operated to maintain lower salinities in upper-bay waters. Salinities generally averaged $<2$ at upper-estuary stations, and 5-20 at lower-estuary stations.

\section{Methods}

Fish were collected 2003-2007 generally once a year during 1-week expeditions that visited several sampling stations. Expeditions were made during mid or late summer, July-October. Exceptions were that fish from higher-salinity stations in lower Barataria Bay were collected only in June, July, and October 2003; some spring collections were made from Barataria Bay in 2003; and fish from upper Breton Sound were collected only in September 2004 and April 2005. Over the 5-yr study period, 67 collections at individual stations were made at upperestuary stations and 9 collections were made at lowerestuary stations. At each station, 30-100 individual fish were collected to represent the range of species, with up to six individuals per species collected to represent a size range, from smallest to largest. Most fish were $5-50 \mathrm{~cm}$ total length, although individuals of some species such as gar and carp were larger, $40-80 \mathrm{~cm}$ and $70-120 \mathrm{~cm}$ total length, respectively, and some species such as killifish and mosquitofish were smaller at $1-3 \mathrm{~cm}$ total length.

Animals were collected with a boat-mounted electrofishing unit from riverine and low salinity estuarine stations. Gill nets and seines were used to collect animals from the more marine portions of estuaries. Fish collected by gill netting were generally dead at the time of collection and frozen shortly thereafter. Electroshocked and seined 


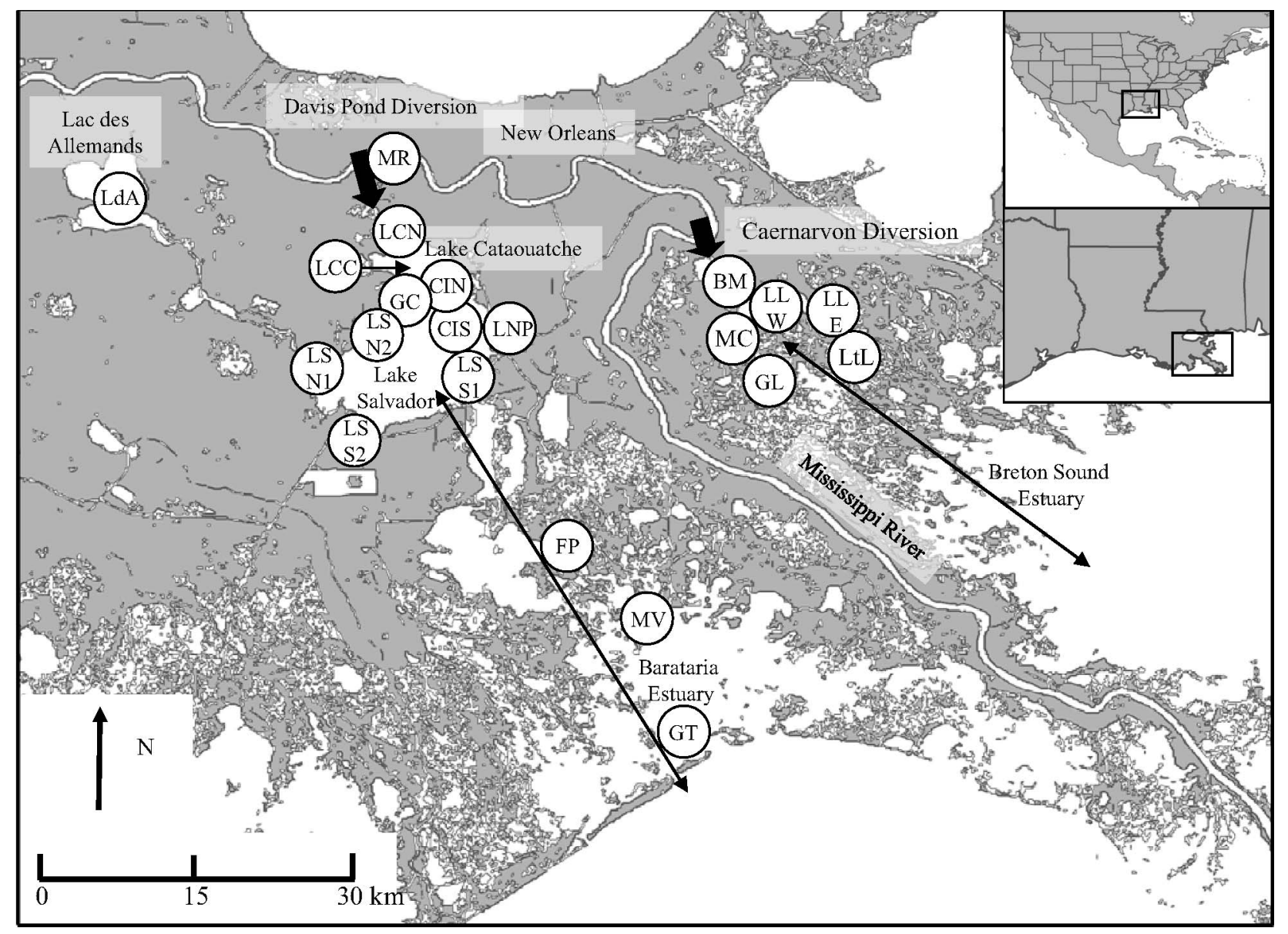

Fig. 1. Sample stations near New Orleans in the two Louisiana estuaries, Barataria Bay and Breton Sound. Key to stations: BM = Big Mar; CIN = Couba Island North; CIS = Couba Island South; GC = Gulf Canal; GL = Grand Lake western shore; GT = Grand Terre; FP = Fisherman's Point; LdA = Lac des Allemands; LCC = Lake Cataouatche Central; LCN = Lake Cataouatche North; LL W = Lake Leary West; LL E = Lake Leary East; LS N1 = Lake Salvador North Marsh No. 1; LS N2 = Lake Salvador North Marsh No. 2; LS S1 = Lake Salvador South shoreline station No. 1; LS S2 = Lake Salvador South shoreline station No. 2; LtL = Little Lake north shore; LNP = Lafitte National Park in Kenta Canal; MR = Mississippi River at Davis Pond diversion structure; MV = Manila Village; $\mathrm{MC}=$ Manuel's Canal.

animals were placed in an ice bath at the time of collection, then transported to the laboratory where they were frozen. All animals were collected under approved guidelines from the Institutional Animal Care and Use Committee at Louisiana State University.

Later fish processing in the laboratory generally involved thawing, measuring of total lengths and blotted wet mass, then dissection of white muscle tissue from dorsal areas. Muscle tissue was cleaned by rinsing in running tap water, then placed in glass vials and allowed to soak 15-60 min in deionized water to remove salt (Fry 2008). The soak water was discarded, and tissues were dried at $60^{\circ} \mathrm{C}$, then pulverized with a Wig-L-Bug automated grinder (Dentsply International). Fish were analyzed as individuals for sulfur stable isotopes following established procedures (Fry 2007) and $\delta^{34} \mathrm{~S}$ values are reported vs. the Canyon Diablo Troilite standard.

Average values are given as means with standard errors, unless otherwise stated. Statistical comparisons among means were done with $t$-tests and Fisher's least significant difference test within the software program Statgraphics
Plus v5.1, with significant differences indicated when $p<$ 0.05 . Errors associated with means are reported as standard deviations and standard errors of the mean. Common names are used for fish species throughout the text; scientific names for these species are given in Tables 1-3.

We used two approaches for differentiating residents from transients at our estuarine study sites. In both approaches, we examined fish community $\delta^{34} \mathrm{~S}$ data for normality, expecting residents to fall within the central part of normal $\delta^{34} \mathrm{~S}$ distributions and transients to be outliers in these distributions. The first approach evaluated normality with the technique of graphical normal equivalent deviates (NEDs; Sokal and Rohlf 1999) that gives straight lines when data are normally distributed and where one unit represents one standard deviation in cases of normal distributions. With this NED approach, one line indicates a normal population and two or more lines indicate presence of more than one normal population. Two straight lines characterized the NED plots at many of our stations, with points near the intersection of lines assigned to one or the other of the lines to yield the maximum sum 
Table 1. Fish residency and transience at three stations in lower Barataria Bay, 2003 (results from Fig. 1, Stas. FP, MV, and GT combined).

\begin{tabular}{|c|c|c|c|c|c|c|}
\hline Species & Scientific name & No. resident & No. transient & Total & $\%$ resident & $\%$ transient \\
\hline 1 Striped mullet & Mugil cephalus & 0 & 9 & 9 & 0 & 100 \\
\hline 2 Threadfin shad & Dorosoma petenense & 0 & 13 & 13 & 0 & 100 \\
\hline 3 Gizzard shad & Dorosoma cepedianum & 1 & 7 & 8 & 13 & 88 \\
\hline 4 Ladyfish & Elops saurus & 6 & 24 & 30 & 20 & 80 \\
\hline 5 Pinfish & Lagodon rhomboides & 2 & 3 & 5 & 40 & 60 \\
\hline $6 \mathrm{Spot}$ & Leiostomus xanthurus & 14 & 10 & 24 & 58 & 42 \\
\hline 7 Leatherjacket & Oligoplites saurus & 6 & 3 & 9 & 67 & 33 \\
\hline 8 Atlantic croaker & Micropogonias undulatus & 23 & 9 & 32 & 72 & 28 \\
\hline 9 Silversides & Menidia beryllina & 14 & 5 & 19 & 74 & 26 \\
\hline 10 Atlantic needlefish & Strongylura marina & 6 & 2 & 8 & 75 & 25 \\
\hline 11 Silver perch & Bairdiella chrysoura & 3 & 1 & 4 & 75 & 25 \\
\hline 12 Sand seatrout & Cynoscion arenarius & 8 & 2 & 10 & 80 & 20 \\
\hline 13 Gulf menhaden & Brevoortia patronus & 23 & 5 & 28 & 82 & 18 \\
\hline 14 Hardhead catfish & Ariopsis felis & 37 & 3 & 40 & 93 & 8 \\
\hline 15 Atlantic threadfin herring & Opisthonema oglinum & 3 & 0 & 3 & 100 & 0 \\
\hline 16 Kingfish & Scomberomorus cavalla & 11 & 0 & 11 & 100 & 0 \\
\hline 17 Spanish mackerel & Scomberomorus maculatus & 16 & 0 & 16 & 100 & 0 \\
\hline 18 Scaled sardine & Harengula jaguana & 6 & 0 & 6 & 100 & 0 \\
\hline Mean & & & & & 64 & 36 \\
\hline SEM & & & & & 8 & 8 \\
\hline
\end{tabular}

of $r^{2}$ values for the lines. This procedure identified sharp or maximum changes in slope from one line to the next.

A second approach for distinguishing residents was developed in upper-estuary sites where multiple mixed populations were common and the NED approach sometimes yielded ambiguous results. At these upperestuary sites, SAV-associated centrarchid fish were considered to best represent resident fish in our samples. Fish ranging from -2 to $2 \%$ vs. the centrarchid $\delta^{34} \mathrm{~S}$ average represented the central range of the normal distribution and were considered resident, as detailed in Results.
Results

To test how well $\delta^{34} \mathrm{~S}$ might record salinity, we compared sulfur isotope profiles for sulfate and fish samples collected across the salinity gradient in Barataria Bay (Fig. 2). The sulfate profiles showed the expected very sharp transition from low values to high and near-constant values at a salinity of about 0.6; fish isotopes followed the same general pattern, but showed a much more gradual transition. Although fish and sulfate values were similar at low salinities, the $14 \%$ average fish $\delta^{34} \mathrm{~S}$ values at higher

Table 2. Residency estimates (as fractions of 1) for centrarchid species using different $\Delta^{34} \mathrm{~S}$ ranges or upper-limit cutoff values.

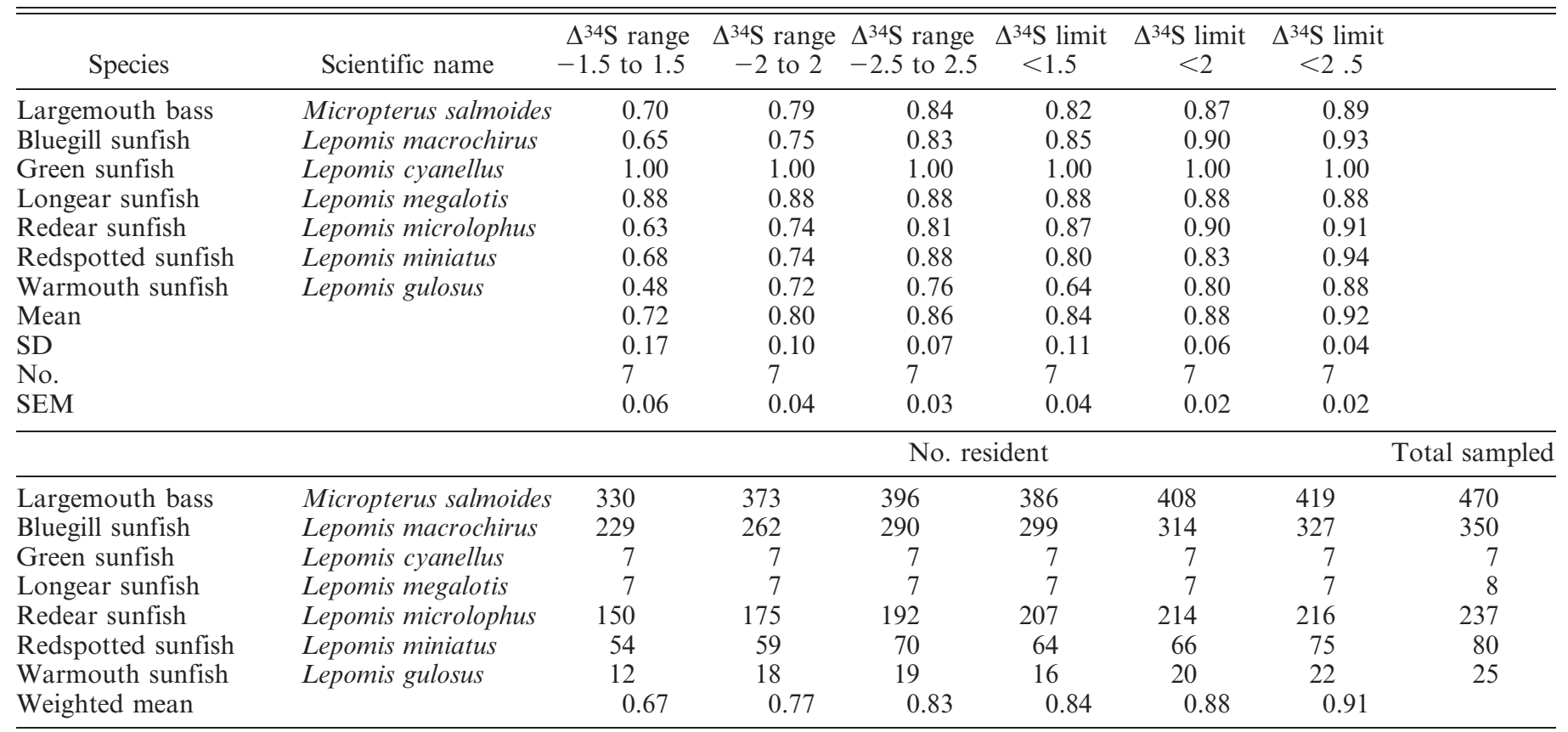




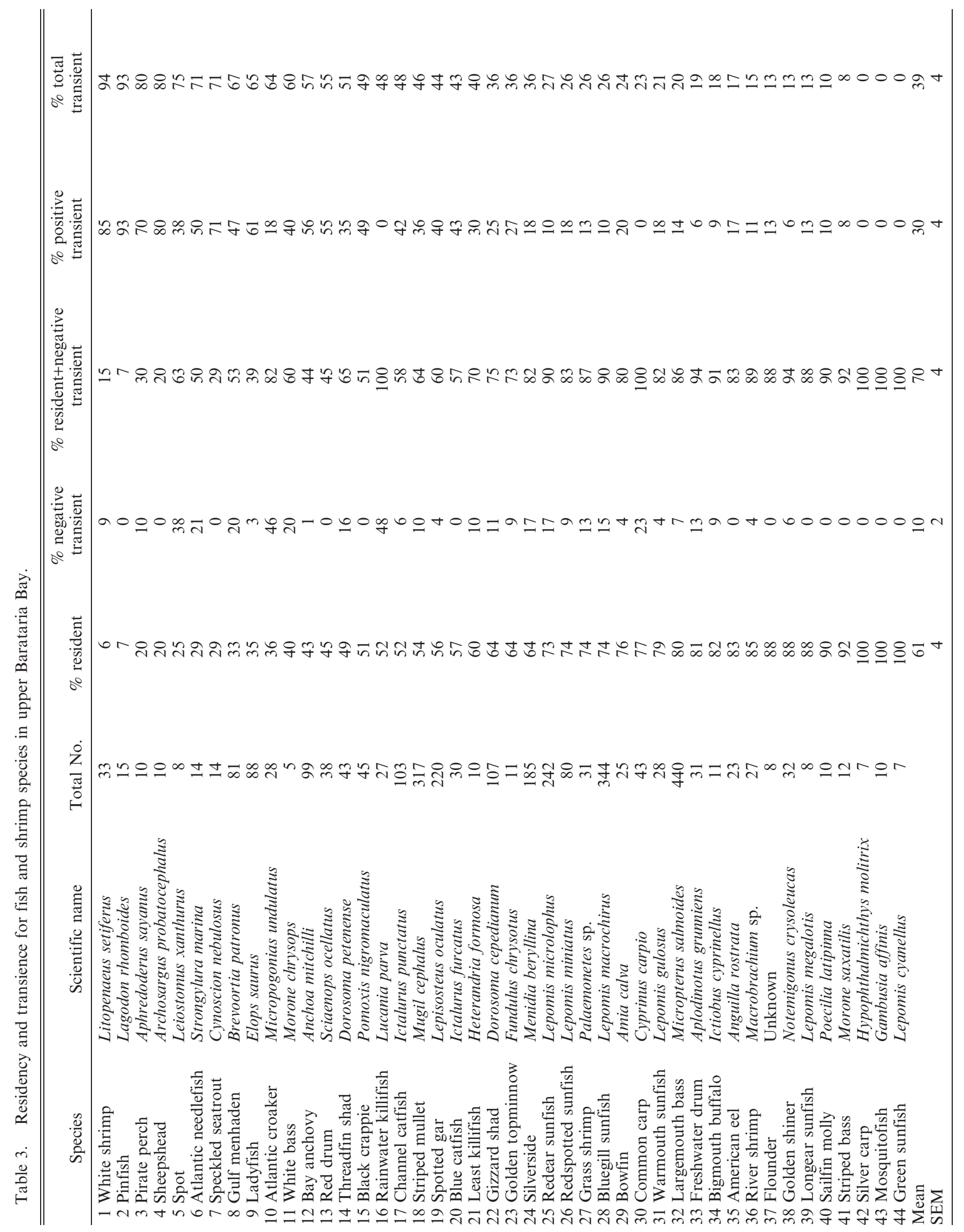




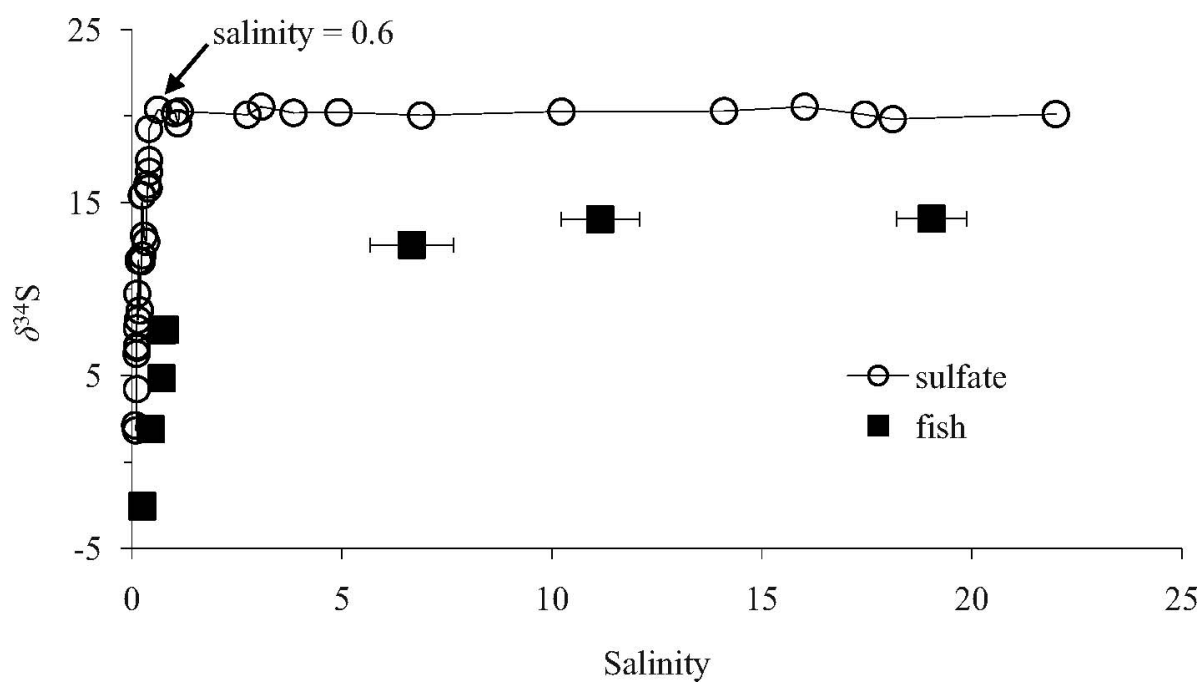

Fig. 2. $\quad \delta^{34} \mathrm{~S}(\%)$ values of sulfate and resident fish vs. salinity in Barataria Bay. Fish samples were collected in May-October 2003 and sulfate samples were collected in January 2008. For sulfate, salinities were measured at the time of collection. For fish, salinities are 6-month AprilOctober averages that were measured in an ongoing water quality monitoring program (E. Swenson pers. comm.). Error bars are SE and are smaller than the data points in some cases.

salinities were about $7 \%$ lower than those of $21 \%$ marine sulfate (Fig. 2).

We first studied the higher-salinity fish communities in lower Barataria Bay (stations Fisherman's Point [FP], Manila Village [MV], and Grand Terre [GT] in Fig. 1) for residency. Using NED plots, data for each of the lowerestuary stations fell along two straight lines (Fig. 3). Examination of the species involved in the group with higher $\delta^{34} \mathrm{~S}$ at each station showed predominantly marine species, and predominantly freshwater or known very mobile species (shad, ladyfish, and mullet) in the group with lower $\delta^{34} \mathrm{~S}$ (Table 1). The higher $\delta^{34} \mathrm{~S}$ values of the first group were those expected for marine residents in the high-salinity lower bay so that these animals with $\delta^{34} \mathrm{~S}$ values falling along the upper line were classified as residents, and animals from lower lines were classified as transients. When data for residents was recalculated as $\Delta^{34} \mathrm{~S}$ (= deviation from the resident $\delta^{34} \mathrm{~S}$ average), the

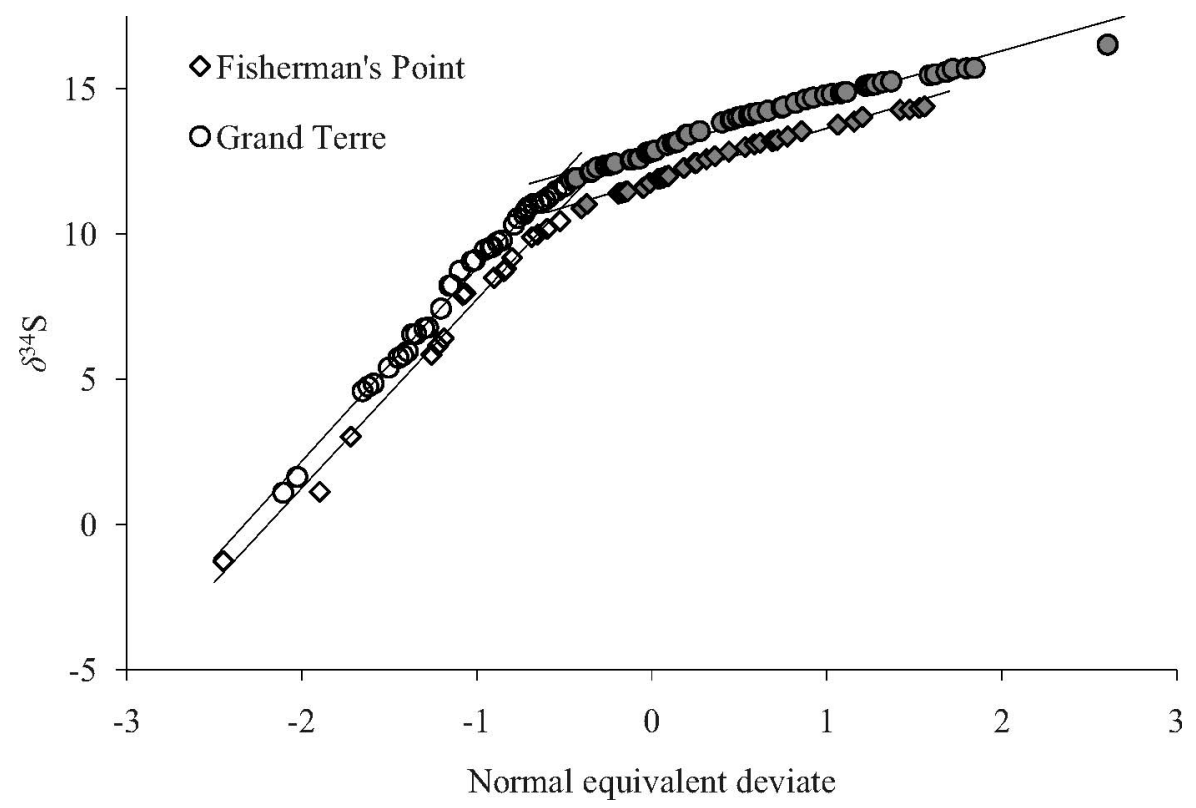

Fig. 3. $\quad \delta^{34} \mathrm{~S}(\%)$ values for individual fish vs. NED for FP and GT, two stations in lower Barataria Bay, 2003. Lines separate samples from each station into two normally distributed populations, transients with lower $\delta^{34} \mathrm{~S}$ values (open symbols) and residents with higher $\delta^{34} \mathrm{~S}$ values (closed symbols). Samples from the third station in lower Barataria Bay, MV (Fig. 1), followed nearly identical trends to those shown here for GT. 


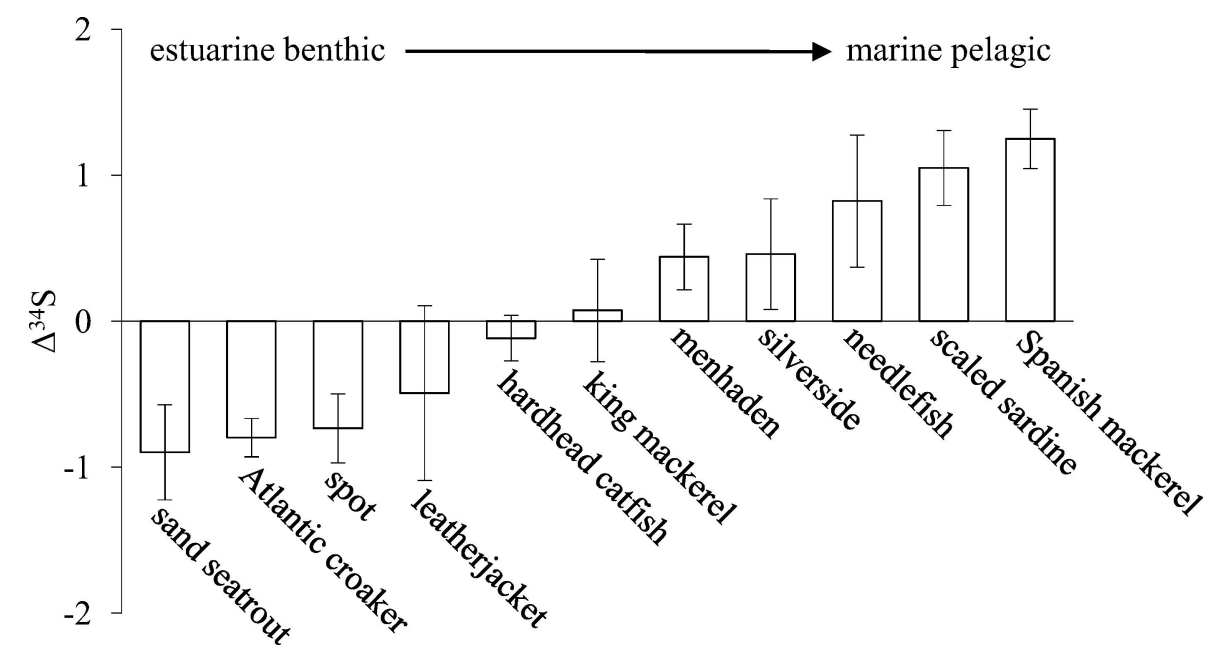

Fig. 4. Sulfur isotope values of resident marine species in lower Barataria Bay plotted as deviations $\left(\Delta^{34} \mathrm{~S}, \%\right)$ from their common average; data combined from all three stations (FP, MV, and GT) of lower Barataria Bay (Fig. 1).

combined data for all three stations fell almost entirely within a $4 \%$ range $( \pm 2 \%$ ) with an overall population SD of $1.1 \%$.

We further examined the resident $\Delta^{34} \mathrm{~S}$ values by species, with species averages ranging from about $-1 \%$ to $+1 \%$ o (Fig. 4). Higher $\Delta^{34} \mathrm{~S}$ values were found in more marine plankton-feeding species and lower $\Delta^{34} \mathrm{~S}$ values were found in more benthic-feeding estuarine species (Fig. 4). Smaller $\Delta^{34} \mathrm{~S}$ differences generally were found among upper-estuary resident species (i.e., $-0.5 \%$ o to $+0.5 \%$ o range for seven centrarchid species) than for the lower-estuary resident species shown in Fig. 4. Overall, these 1-2\%o species-level $\Delta^{34} \mathrm{~S}$ variations related to different planktonic vs. benthic feeding strategies were relatively minor compared to the approximately $23 \%$ gradient in average fish $\delta^{34} \mathrm{~S}$ across the estuary (Fig. 2).

We extended the lower-estuary studies into the upper estuary in 2003, finding that the NED graphic approach worked reasonably well at all stations and showed that most $\delta^{34} \mathrm{~S}$ values fell along one straight line and thus were part of normally distributed populations, with a few outliers (Fig. 5). These results indicated largely resident populations in the upper estuary with the majority of animals at each station having $\delta^{34} \mathrm{~S}$ values in a narrow range $< \pm 2 \%$ (Fig. 5). The studies also allowed comparisons between stations and some inferences about the spatial scale of residency. Separation between upperestuary populations was occurring at scales of a few kilometers, and especially two pairs of upper-estuary stations separated by $4 \mathrm{~km}$ showed quite different NED distributions, indicating separate populations. Pair 1 was Lake Cataouatche North (LCN) vs. Couba Island North (CIN), which respectively represent the northern and southern shores of Lake Cataouatche, and pair 2 was CIN vs. Gulf Canal (GC), where the GC station was about $4 \mathrm{~km}$ to the west of CIN (Figs. 1, 5). Samples collected in 2007 at LCN, the northern edge of Lake Cataouatche, showed that even finer-scale differences among populations could be detected in some low-salinity situations, with populations within the marsh holding pond area at the northern edge of the lake being lower in $\delta^{34} \mathrm{~S}$ than populations collected $<0.1 \mathrm{~km}$ offshore of this marsh area in the open lake (Fig. 5; compare LCN 07 inside vs. LCN 07 outside). In contrast to these examples from lowest-salinity stations near points of Mississippi River inflow where $\delta^{34} \mathrm{~S}$ changed rapidly over short spatial scales, resident populations living downestuary at higher $(>2)$ salinities had very similar $\delta^{34} \mathrm{~S}$ values (Fig. 5; compare GC and Couba Island South [CIS] or GT and MV). Overall, these geographic comparisons indicated good resolution of movement at small $0.1-4-\mathrm{km}$ scales for low-salinity $(<2)$ upper-estuary stations, and good detection of long-range migrants from the upper estuary into the lower estuary at a coarser spatial scale of $10-30 \mathrm{~km}$.

In the upper estuary, we also employed the NED approach to identify normally distributed populations that could be considered potentially resident, finding that across 67 collections made at upper-estuary stations, SDs and ranges averaged $1.13 \pm 0.06 \%$ and $4.0 \pm 0.2 \%$, respectively. Results from these 67 collections divided into two normally distributed populations, with $1 / 3$ of the collections belonging to one population with lower average values of $\mathrm{SD}=0.57 \pm$ 0.03 and range $=2.0 \pm 0.1 \%$, and the remaining $2 / 3$ of the collections comprising the other population with higher average values of $\mathrm{SD}=1.42 \pm 0.06 \%$ and range $=5.1 \pm$ $0.2 \%$. Upper estuary examples shown in Fig. 5 (all stations except GT, MV, and FP) exemplify stations with the lower range of values indicative of strong residency and homogenous foods. However, the NED approach was problematic at the other $2 / 3$ of the collections made at upper-estuary stations where NED plots were linear but the range of values often exceeded $10 \%$, conditions consistent with multiple well-mixed populations. To better identify the true residents in these upper-estuary samples, we developed a second approach (besides NEDs) that also was based on normal distributions.

Our second approach of assessing residency considered that true residents should have a narrow SD and range for 


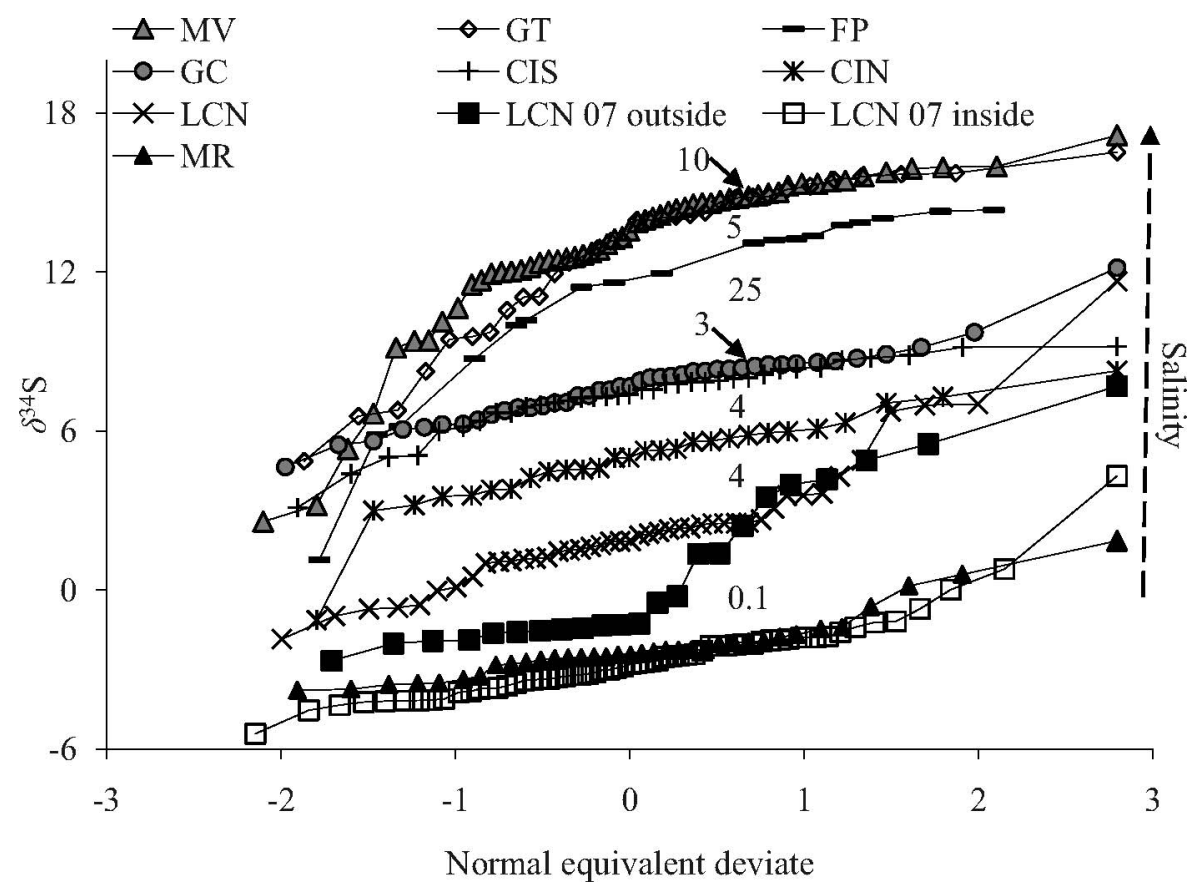

Fig. 5. As Fig. 3, but stations include upper-estuary as well as lower-estuary stations in Barataria Bay, 2003. The station data also represent a salinity gradient, high salinity and high $\delta^{34} \mathrm{~S}$ at top for the more marine (lower-bay) stations (FP, MV, GT) vs. low salinity and low $\delta^{34} \mathrm{~S}$ towards the bottom for more freshwater (upper-bay) stations. Numbers between the data lines indicate distance $(\mathrm{km})$ between successive stations. Some data for 2007 are included from the LCN and marsh stations to illustrate isotope differences that can occur between populations living close together, within $0.1 \mathrm{~km}$. Station locations are shown in Fig. 1.

$\delta^{34} \mathrm{~S}$, and we pursued this idea by examining seven species of centrarchids (six sunfish species + largemouth bass) that were associated strongly with SAV in our sampling and could be expected to be mostly resident. We calculated $\Delta^{34} S$ values for all the 1140 centrarchids of this study $\left(\Delta^{34} \mathrm{~S}=\right.$ fish $\delta^{34} \mathrm{~S}-$ station $\delta^{34} \mathrm{~S}$, where the station $\delta^{34} \mathrm{~S}$ was the average of all centrarchids at a station), and found that we could fit a normal curve to the central part of the data that we took to represent residents (Fig. 6). This classification meant that there were two types of transients, either negative transients with $\Delta^{34} \mathrm{~S}<-2 \%$ or positive transients with $\Delta^{34} \mathrm{~S}>2 \%$, as well as residents with $\Delta^{34} \mathrm{~S}$ values in the central $4 \%$ range from $-2 \%$ to $+2 \%$ o $(0 \pm 2 \%$ )

The exact position of this cutoff at $\pm 2 \%$ was chosen carefully to represent the best balance between residents and transients, so that, for example, although there is a tail of residents misclassified as transients in the $>2 \%$ class (Fig. 6), there is an equal misclassification of transients within the resident class at $<2 \%$. These misclassifications compensated so that the $\pm 2 \%$ rule gave the most balanced and accurate division between residents and transients. Use of other cutoff values shifted the average results without affecting patterns in substantial ways (Table 2). For example, the use of $\pm 2 \%$ gave the overall weighted average result that centrarchids were $77 \%$ resident, a \pm $1.5 \%$ cutoff gave a lower $67 \%$ result, and a larger cutoff of $\pm 2.5 \%$ gave an $83 \%$ result, but in the end, these $67-83 \%$ estimates were all fairly similar and supported the initial assumption of strong residency for centrarchids.
We used the $\pm 2 \%$ cutoff to evaluate residency for species and stations in the upper parts of Barataria and Breton Sound estuaries. For example, Fig. 7 shows data for three upper-estuary species that were each collected at nine stations. Largemouth bass were strongly resident at all stations except Lake Salvador South 1 (LS S1), an openshore station without SAV in southeastern Lake Salvador. Spotted gar and mullet were also very transient at this station (Fig. 7), which was judged of poor quality by human observers and where fish were not abundant. At the other eight stations, gar generally showed less residency than largemouth bass, with frequent positive $\Delta^{34} \mathrm{~S}$ values expected for transient animals spending some time in higher-salinity habitats. Mullet showed the most mixed pattern, with strong transience indicated for several stations but strong residency at others. Strong residency was observed at SAV-rich canal and back-marsh stations (Fig. 7; Lac des Allemands [LdA], CIS, GC, Lake Salvador South 2 [LS S2], Lafitte National Park [LNP]) and strong transience was observed at a mid-lake station and in the Mississippi River (Fig. 7; Lake Cataouatche Central [LCC] and Mississippi River [MR]).

We summarized patterns of within-species residency such as those shown in Fig. 7, finding that average residency within a species was approximately $2 / 3$ resident and $1 / 3$ transient (Tables 1,3 ). However, some species were more resident than others. In the lower estuary, 12 of 18 species were $>2 / 3$ resident, 2 were $1 / 3-2 / 3$ resident, and 4 of the 18 species were less than $1 / 3$ resident and thus mostly 


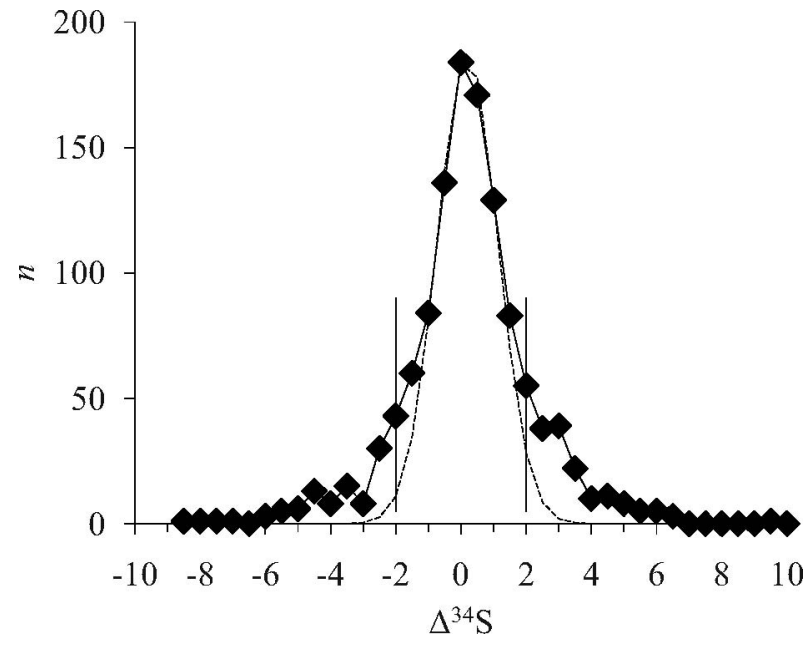

Fig. 6. Histogram of station-normalized $\left(\Delta^{34} \mathrm{~S}, \%\right)$ sulfur isotope distributions for 1140 centrarchids (six sunfish species plus largemouth bass) collected in this study. Dashed line shows a normal curve fitted to the central part of this distribution with SD $=0.89$. Vertical lines at $\pm 2 \%$ are empirical cutoff values used to categorize fish as resident $(-2$ to $+2 \%$ ), negative transients $(<-2 \%)$, and positive transients $(>2 \%)$, as explained in the text.

transient (Table 1). For the upper estuary, 20 of 44 species were $>2 / 3$ resident, 16 were $1 / 3-2 / 3$ resident, and 8 species were $<1 / 3$ resident and thus mostly transient (Table 3 ). Marine species accounted for this last category of mostly transient species in the upper estuary, and these positive transients were $3 \times$ more abundant than negative transients (Table 3). If marine species were excluded from the upperestuary data, average "\% resident" or "residency" for upper-estuary species increased from $61 \%$ to $70 \%$, and similarly if mullet, shad, and ladyfish were excluded from the lower-estuary data, average residency for lower-estuary species increased from $64 \%$ to $79 \%$. Overall, the results of Tables 1 and 3 indicate that the species pool was fairly similar in the upper and lower estuary in terms of proportions of residents and transients. This similarity extended to the actual community-level estimates of percentage resident and percentage transient as well. That is, when calculated across all collections representing multiple sites and individuals of the various species, communities were $65 \% \pm 3 \%$ (average \pm SEM) resident in the upper estuary and $64 \% \pm 4 \%$ (average \pm SEM) resident in the lower estuary. These values are not significantly different (unpaired $t$-test, $t=0.155$, df $=66$, $p=0.88$ ), and indicate that the fish communities in both lower and upper estuaries were composed of about $2 / 3$ residents and $1 / 3$ transients.

There were some surprising patterns of transience within species. Specifically, transience was fairly evenly distributed across size ranges and not localized just to larger fish. Figure 8 illustrates these results for largemouth bass (Fig. 8A) and bluegills (Fig. 8B), with both species showing a fairly even pattern of transients occurring across the whole size range, although somewhat less transience was indicated for the smallest bluegills (Fig. 8B). Similar plots (not shown) for redear sunfish, gar, and mullet gave results
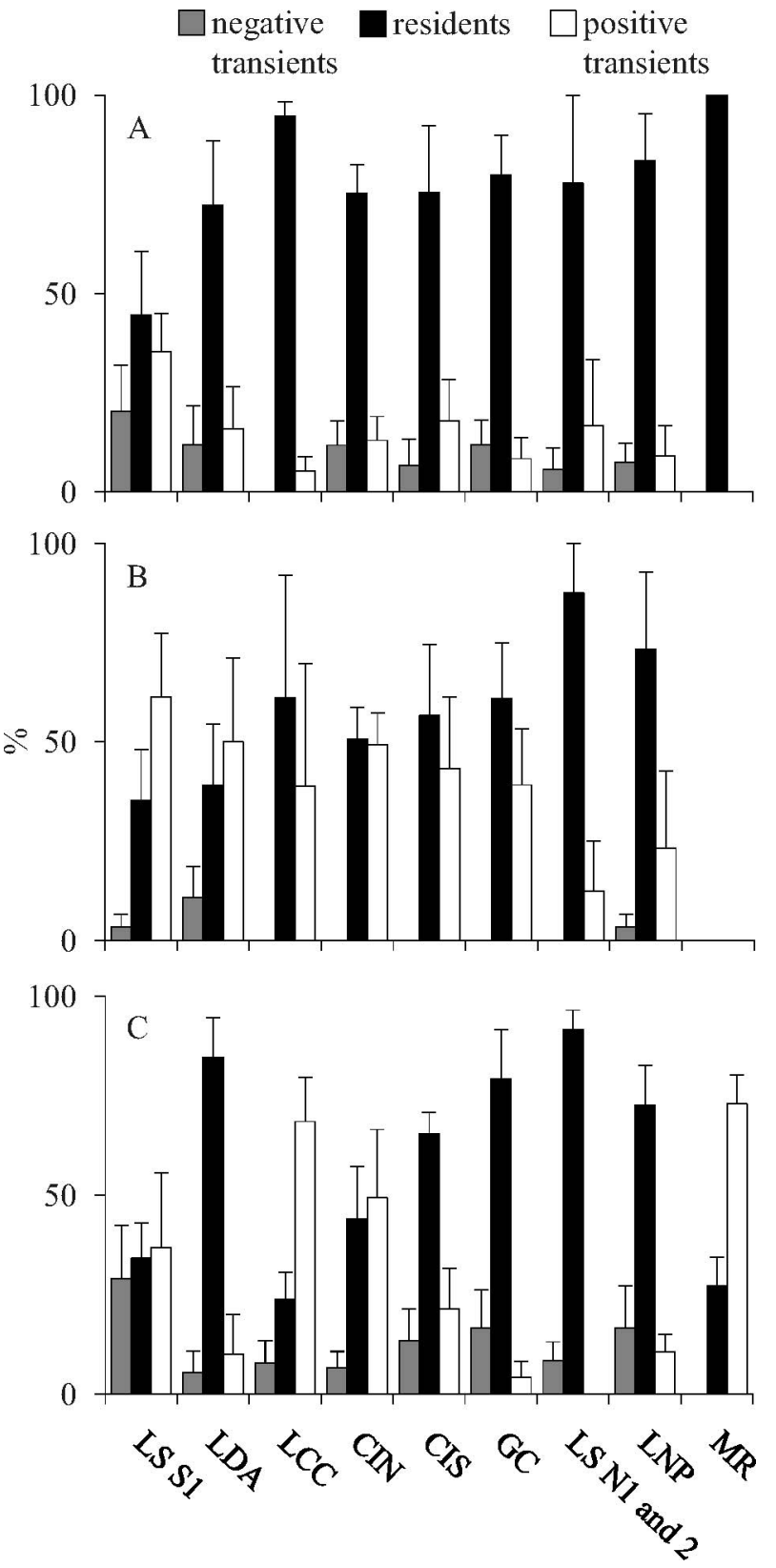

Fig. 7. Percentage residency and transience at nine stations for three common upper-estuary species: (A) largemouth bass, (B) spotted gar, and (C) mullet. Negative transients have $\Delta^{34} \mathrm{~S}<$ $-2 \%$ vs. station average at $0 \%$, residents have $\Delta^{34} \mathrm{~S}=-2$ to $+2 \%$, and positive transients have $\Delta^{34} \mathrm{~S}>2 \%$, as explained in the text. Station locations are shown in Fig. 1; error bars are SEM.

very similar to those shown for largemouth bass, i.e., a fairly even pattern of transients occurring among both small and larger fish. Also, if $\Delta^{34} \mathrm{~S}$ data were recalculated with small $<100-\mathrm{mm}$ centrarchids rather than all centrarchids combined for station averages, the patterns remained the same, i.e., there was still substantial transience among small as well as large individuals. Overall, these results indicated that substantial movement among small individuals was ongoing and common among upperestuary stations and salinity zones. 


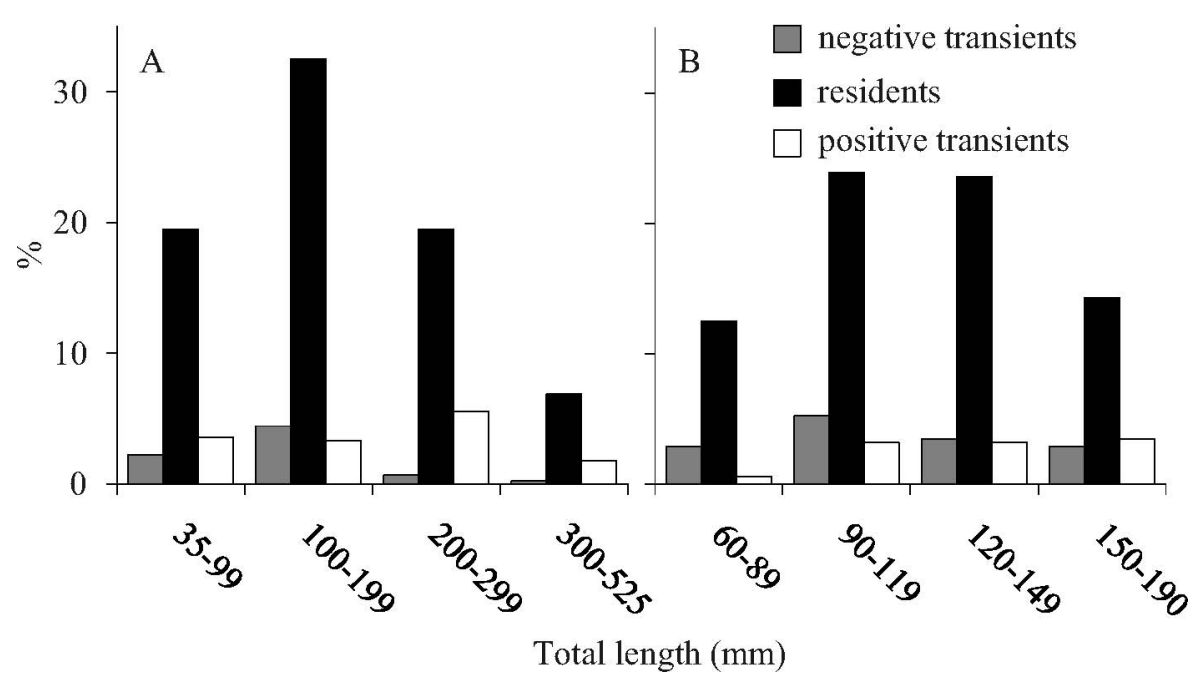

Fig. 8. Size-frequency diagrams showing residency and transience for (A) largemouth bass and (B) bluegills. Y-axis is percentage of total number of fish measured for each species.

The larger-scale geographic pattern of community-level residency and transiency was also of interest. Community residency was highest $(82 \% \pm 2 \%$, average \pm SEM $)$ in the Mississippi River, which could be expected to provide a consistent freshwater habitat. Residency was significantly lower $(56 \% \pm 4 \%$, average $\pm \mathrm{SEM}$; unpaired $t$-test, $t=$ 3.83 , $\mathrm{df}=17, p=0.0013$ ) in Breton Sound, which had been receiving diversion inflows from the Mississippi River for 13 yr. Similar results were also evident in upper Barataria Bay, where there was a significant decline (unpaired $t$-test, $t=2.21, \mathrm{df}=37, p=0.033$ ) in residency after the diversion started in 2004, i.e., residency was $77 \% \pm 4 \%$ (average \pm SEM) in 2003 vs. $66 \% \pm 3 \%$ (average \pm SEM) for 2004 2007. At this same time, residency in LdA, a control station in upper Barataria Bay unaffected by the diversion, showed the opposite trend of increasing rather than decreasing residency, i.e., residency was $60 \% \pm 13 \%$ (average \pm SEM) in 2003 vs. $88 \% \pm 7 \%$ (average \pm SEM) for 2004-2007. The possible effects of diversions to decrease residency was studied in more detail by comparing Breton Sound data for September 2004 and April 2005 (Fig. 9). This comparison showed surprising results, i.e., that strong winter + spring diversions had the effect of increasing the $\delta^{34} \mathrm{~S}$ averages for April fish collected nearest the diversion at Big Mar (BM) and Lake Leary West (LLW), rather than decreasing $\delta^{34} \mathrm{~S}$ values towards those measured in riverine fish (Fig. 9). These results were consistent with relatively low residency in the Breton Sound diversion area, and mean residency was not significantly different in the September 2004 and April 2005 collections, $55 \% \pm 7 \%$ and $57 \% \pm 5 \%$ (average $\pm \mathrm{SEM}$; unpaired $t$-test, $t=0.235$, df $=11, p=0.82$ ), respectively.

\section{Discussion}

The main underlying assumption in this work was that fish $\delta^{34} \mathrm{~S}$ values display a regular relationship with salinity. This proved to be the case (Fig. 2), even though the offset between sulfate and fish $\delta^{34} \mathrm{~S}$ did not appear to be constant.
Fish $\delta^{34} \mathrm{~S}$ values averaged about 7\%o lower than sulfate $\delta^{34} \mathrm{~S}$ in the lower, more marine portion of the estuary. The 7\% lower values are consistent with sedimentary sulfides entering the food web via benthic bacteria and microphytobenthos (Fry 2008), with sulfides having low $\delta^{34}$ S values (Bates et al. 2002). The $\delta^{34} \mathrm{~S}$ values measured for resident fish in the lower estuary were in the same range of 13.5-17\% reported for barnacles from lower Barataria Bay (Fry and Smith 2002). These values may represent open bay conditions where planktonic foods are relatively important, with lower $\delta^{34} \mathrm{~S}$ values of $6-12 \%$ observed in animals from

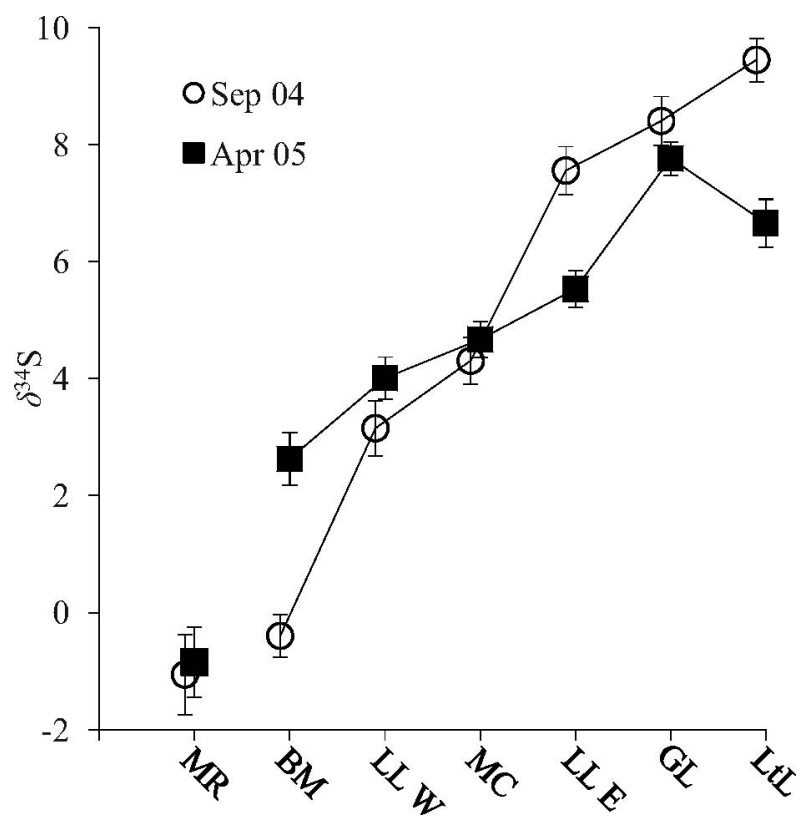

Fig. 9. Average fish $\delta^{34} \mathrm{~S}(\%)$ for upper-bay stations in Breton Sound that have had long-term diversion inputs. Collections in September 2004 (open circles) represent summer low flow conditions; collections in April 2005 (closed squares) represent conditions towards the end of the spring season of high river inputs. Station locations are shown in Fig. 1. 
local salt marshes where benthic foods are relatively more important (Fry 2008). The shallow nature of the bays studied here may allow some entry of sulfides into benthic foods that are resuspended and used by fish and filterfeeding barnacles. Occasional $10-14 \%$ o $\delta^{34} \mathrm{~S}$ values observed in marine species in the lower bay may indicate use of peripheral marsh areas, but this use appeared relatively minor for the larger $(>10 \mathrm{~cm})$ fish collected by gill nets in open bays of this study.

In the upper bay, there is less salinity, less sulfate (Bryan et al. 1992), and presumably less production of sulfide, and a closer correspondence between fish and sulfate $\delta^{34} \mathrm{~S}$ was observed. In the Mississippi River itself, there was little average difference in fish and sulfate $\delta^{34} \mathrm{~S}$, with both averaging near $-2 \%$ over the 5 -yr study period. Besides having lower sulfate concentrations, the river is turbulent and oxidizing, which are conditions that favor sulfide loss rather than sulfide accumulation. However, stagnant conditions dominate in some back-marsh areas, and sulfides do accumulate in pore waters of some low salinity Louisiana marshes (Swarzenski et al. 2008). Sulfate reduction in freshwater systems recently has been reported to produce $1-2 \%$ lower $\delta^{34} \mathrm{~S}$ values in benthic vs. pelagic fish (Croisetiere et al. 2009), consistent with some entry of sulfides into freshwater food webs. Entry of such sulfides into local benthic food webs could account for some of the negative $\Delta^{34} \mathrm{~S}$ transients observed in the Mississippi River and in upstream areas like LdA that had lowest salinities measured in this study. These negative transients were present at low abundance at many upper-estuary stations and probably represented transients from nearby backwaters and marsh areas. These negative transients could be counted as residents if station concepts were expanded to include fringing marshes, increasing average upper-estuary station residency from $60 \%$ to $70 \%$ (Table 3 ). The remaining animals were positive transients in the upper estuary and were most often marine species that represented true transients in upper-estuary samples.

Beyond the assumption that fish $\delta^{34} \mathrm{~S}$ is related to salinity, we also assumed that tests for normality could be used to distinguish resident fish from transient fish. Fish feeding together will integrate isotope signals from the diet and typically converge to a narrow range of isotope values (Fry et al. 1999; Wells et al. 2008). The $\pm 2 \% \delta^{34}$ S range derived here for field populations is slightly larger than the $\pm 0.7-1.4 \%$ o $\delta^{34} \mathrm{~S}$ ranges for laboratory fish fed a uniform diet (Hesslein et al. 1993; Barnes and Jennings 2007), and the larger field range probably reflects some dietary heterogeneity in prey availability and prey isotopic compositions that prevails for natural populations (Fry et al. 1999). Our estimate of a $\pm 2 \%$ range for residents emerged from independent analyses of lower-estuary fish and of centrarchids in the upper estuary. Larger ${ }^{34} \mathrm{~S}$ ranges and variances might be expected for upper-estuary stations where sulfate concentrations and isotopes can change markedly with only small changes in salinity (Fig. 2). But average standard deviations in the $\delta^{34} \mathrm{~S}$ values at stations in the upper estuary (all fish) and lower estuary (resident fish only) were identical at $1.1 \%$, probably indicating that effects of fluctuating salinity in upper-estuary stations were not strong. Rather, it is likely that the fish isotope values reflect salinity and dietary regimes integrated over several months of fish growth preceding animal collection, and that this time integration helps stabilize the relationship between salinity and fish $\delta^{34} \mathrm{~S}$. Generally, the period of time integration represented by fish $\delta^{34} \mathrm{~S}$ varies with fish size, growth, and metabolic rate (Tarboush et al. 2006; Hoffman et al. 2007). Recent isotope turnover models for larger estuarine fish show that isotope time integrations of 1 6 months are not uncommon (Buchheister and Latour 2010), and may apply to fish of this study that were mostly of moderate total lengths $(5-50 \mathrm{~cm})$ and were collected towards the end of summer growing seasons in estuarine waters that were near $30^{\circ} \mathrm{C}$. Because the turnover times are probably $<$ 6 months, results of this study only address the main springsummer growing season, so that further work would be needed to clarify residency patterns in winter months.

The decision to make a binary, "either-or" classification of transients vs. residents meant that the classifications employed here are broadscale and general, so that more specific information is often lacking. For example, transients might include various types of animals. Some transients could have arrived some time ago but not yet have equilibrated enough with the resident diet to pass the threshold cutoff values (Table 2) to be considered resident. And it was also possible that these animals were true recently arrived transients that had been feeding mostly at other stations where salinity regimes and diets were fairly similar, but not identical. Both these alternatives were lumped together under transients in our binary classification scheme. It was also true that our binary $\delta^{34} \mathrm{~S}$ classifications are based on probabilistic (normal) distributions of $\delta^{34} \mathrm{~S}$ values, did not reflect physical tagging of individual fish, and thus were more subject to error. And it was evident that fish residency measured by the $\delta^{34} \mathrm{~S}$ approach applies to a broader salinity zone and so is not just confined to a particular location when surrounding locations contain similar vegetation and share a similar salinity regime. These and similar concerns lead to the view that the isotope results are best used for comparisons among averaged results for species, stations, or regions, rather than at the very specific level of individual fish, and it is these average comparisons for species and station that we have emphasized in our presentation of results (Tables 1, 3; Figs. 7-9).

In reality, there was no a priori way of knowing if the $\delta^{34} \mathrm{~S}$ approach would really give valid estimates of residency, and so this study was in many ways a test case or validation study. The main criticism that could be leveled is that no independent tagging studies were conducted at the same times and places that we did the $\delta^{34} \mathrm{~S}$ measurements; unfortunately, the labor-intensive tagging work was simply beyond the scope of this study. Instead, four general findings showed that the $\delta^{34} \mathrm{~S}$ approach was giving reasonable estimates of residency. (1) Analysis of $\delta^{34} \mathrm{~S}$ values for lower-estuary predominantly marine fauna (Table 1, species 6-18) and upper-estuary centrarchids (sunfish + largemouth bass, Table 2) both showed expected high residency. (2) Most transients in the lower estuary (Table 1, species 2-4) were correctly identi- 
fied as species from the upper estuary, and conversely, most transients in the upper estuary (Table 3, especially species 1,2 , and 4-13) were correctly identified as marine species from the lower estuary. (3) Species such as mullet and shad that are known to range widely through estuaries were the most transient of species (Table 1). (4) An open shoreline station in southern Lake Salvador that lacked SAV, had sparse fish, and seemed of low quality to human observers showed least fisheries residency and most average transience of all stations sampled (Fig. 7, LS S1 station).

In addition to these general findings, there was also other suggestive evidence for single species such as spotted gar that the $\delta^{34} \mathrm{~S}$ approach gave reasonable estimates of movement. The gar $\delta^{34} \mathrm{~S}$ values showed a high frequency of positive transients (Fig. 7) that was not readily expected given the observed high abundance of gar in SAV beds during the summer collections. But among the upper-estuary species that have strong freshwater affinities, gar are often found in higher-salinity habitats and may move downestuary to overwinter in deeper depressions (Lambou 1952; Snedden et al. 1999; Love 2004). Gar are long-lived species (Love 2004) and consume marine species such as blue crabs (Lambou 1952), so that partial retention of the marine $\delta^{34} \mathrm{~S}$ signal from winter diets could explain the high $\delta^{34} \mathrm{~S}$ values observed for upper-estuary gar collected in summer. In this case, the $\delta^{34} \mathrm{~S}$ approach would agree with previous observations about fish movement in Louisiana coastal waters.

Against this background of finding expected and reasonable results at the whole community and species level, the $\delta^{34} \mathrm{~S}$ approach also gave four quite unexpected findings. (1) Normally transient species such as mullet were sometimes quite resident, especially in back canals and marshes (Fig. 7). (2) Small fish were as transient as larger fish for many species (Fig. 8). (3) Diversions of Mississippi River water decreased residency over the longer-term operation of a diversion at Breton Sound (see Results). (4) Diversions of Mississippi River water into Breton Sound in spring of 2005 led to more mixed populations of estuarine fish, rather than fish acquiring a strong riverine signal (Fig. 9). The reader must judge independently if these four unexpected findings invalidate the $\delta^{34} \mathrm{~S}$ approach, or whether the approach is valid and just shows new and unexpected sides of estuarine fish biology. The authors favor the latter explanation because of the several expected findings listed in the previous two paragraphs.

The general picture we arrive at from the $\delta^{34} \mathrm{~S}$ studies is that there is usually strong residency among estuarine fish, with two important exceptions. The exceptions are that some species such as mullet seem nomadic, although individuals within these species occasionally seem to become resident if conditions are right. The other exception is that at least some individuals of all species and sizes seem to be moving at all times; perfect residency was rare. Perhaps this means that estuaries are crowded, or perhaps this means that there is a subset of individuals in each species that pursue a transient phase in their lives as a strategy to find a favorable place for further growth.

These general ideas can help account for the observation that diversions seemed to mix populations and decrease residency. It was surprising that fish in Breton Sound collected after the high river inflows of spring 2005 did not become more like riverine fish with low $\delta^{34} \mathrm{~S}$ values. An explanation would be that although some upper-estuary fish moved downestuary at the surface with the flowing river water, there also was some countercurrent upstream movement along the bottom for lower-estuary fish moving back towards the river. Previous studies of sulfur isotopes in brown shrimp of this same area have led to similar hypothesized upestuary faunal movements (Rozas et al. 2005). Enhanced production may be occurring in these diversion-affected areas (Day et al. 2009), but homogenization of the fisheries fauna indicated by the sulfur isotope results (Fig. 9) is also accompanied by simplification of ecosystem structure (Rozas et al. 2005). Further studies are needed in other systems to better understand and assess the positive and negative effects of river inputs on residency.

Combining other tracers such as $\delta^{13} \mathrm{C}$ and $\delta^{15} \mathrm{~N}$ in fish tissues and $\delta^{18} \mathrm{O}$ in fish otoliths with $\delta^{34} \mathrm{~S}$ measurements will likely deepen our understanding of estuarine fish movements, increasing our ability to discern residency and more precisely define spatial scales of movement (Thorrold et al. 2002). Use of multiple isotope tracers to study animal movement is increasing (Hobson and Wassenaar 2008; Hoffman et al. 2010), but more research is needed to clarify the best mix of traditional tags and natural chemical markers for studying movement of estuarine fish. The chemical marker approaches have the disadvantage of less site specificity, but do apply more broadly to larger estuarine areas and can be measured in all animals without time-consuming mark-recapture efforts. Commonly measured stable isotopes of hydrogen, carbon, nitrogen, oxygen, and sulfur all show strong salinity-related patterns in estuarine biota (Fry 2002), and using a combination of these markers to study fish movement will likely narrow the broadly resolved salinity zones identified in this study by sulfur isotopes alone. In this regard, it may be that hydrogen and oxygen isotopes are more useful additions to the sulfur isotope approach than are nitrogen and carbon isotope measurements, because the nitrogen and carbon isotopes strongly record food web dynamics (Hoffman et al. 2010) and are thus somewhat confounded indicators of salinity signals in estuaries. Further research is needed to test whether hydrogen and oxygen isotope measurements in fish tissues and body water can improve salinity zone resolution achievable by $\delta^{34} \mathrm{~S}$ alone. Using a wider suite of trace metals and their isotopes (Weiss et al. 2008) as natural chemical tags may improve resolution of sites as well as salinity zones, and analyzing inorganic constituents of fish blood such as sulfate may provide short-term indicators of residency for comparison to the longer-term indicators present in fish muscle. Stable isotope clocks based on turnover kinetics for single and multiple tissues are possible to construct for more detailed hindcasts of the movements of fish individuals and populations (Phillips and Eldridge 2006; Guelinckx et al. 2008).

We do not know the ultimate controls of patterns of fish residency and transience in these estuarine communities. However, in this study, highest residency was found at backwater upper-estuary sites with rich SAV beds, and lowest residency was found along open shores of well- 
mixed windy bays. These observations suggest that habitat influences residency, with higher-complexity SAV beds associated with high residency. There is also the curious observation that on average, residency was $2 / 3$ and transience $1 / 3$ in both upper and lower bays, in spite of upper bays' generally having rich SAV beds and lower bays' lacking these features. Lower bays were muddy open bay systems that were well mixed by winds. The large-scale similarity in residency patterns for the upper and lower bays in spite of different habitat conditions may mean that biological controls also are important controls of patterns of residency. For example, biological interactions among individual fish and species packing considerations (Seehausen and Bouton 1997) might prove important in determining fish residency when, for example, resident fish aggressively defend home ranges from transients. In any case, the emerging isotopic and chemical marker approaches seem well suited to exploring how physical and biotic factors interact to control fish transience and residency in estuarine systems. Because freshwater-marine mixing is the main defining characteristic of estuaries and because the $\delta^{34} \mathrm{~S}$ sulfate system is closely linked to salinity, the $\delta^{34} \mathrm{~S}$ approach is likely to be quite general and applicable across many other estuaries, so that future work can test some of the initial observations made here.

\section{Acknowledgments}

Sunil Addepalli, Pamela MacRae, Gary Peterson, Zoraida Quinones, Barack Bhallam Venkaat, and Bjoern Wissel assisted with fisheries collections. Elizabeth Ecker, Elizabeth Gallagher, Madeleine Grant, Tracy Pasqua, Rebecca Sylvestri, and Julia Wheatley were undergraduate students from Louisiana State University who helped with laboratory preparation of samples and data entry. Erick Swenson provided salinity data and graphical assistance. Beryl Ody helped with manuscript preparation, and two anonymous reviewers provided constructive comments. This work was supported by award 16OP2670 from the National Oceanic and Atmospheric Agency.

\section{References}

Barnes, C., And S. Jennings. 2007. Effect of temperature, ration, body size and age on sulphur isotope fractionation in fish. Rapid Commun. Mass Spectrom. 21: 1461-1467.

Bates, A. L., W. H. Orem, J. W. Harvey, and E. C. Spiker. 2002. Tracing sources of sulfur in the Florida Everglades. J. Environ. Qual. 31: 287-299, doi:10.2134/jeq2002.0287

BECK, M. W., AND OTHERs. 2001. The identification, conservation and management of estuarine and marine nurseries for fish and invertebrates. BioScience 51: 633-641, doi:10.1641/ 0006-3568(2001)051[0633:TICAMO]2.0.CO;2

Boesch, D. F., And R. E. Turner. 1984. Dependence of fishery species on salt marshes: the role of food and refuge. Estuaries 7: 460-468, doi:10.2307/1351627

Bryan, C. F., D. A. Rutherford, and B. Walker-Bryan. 1992. Acidification of the lower Mississippi River. Trans. Am. Fish. Soc. 121: 369-377, doi:10.1577/1548-8659(1992)121 $<0369$ :AOTLMR $>2.3$.CO;2

Buchheister, A., AND R. J. LAtour. 2010. Turnover and fractionation of carbon and nitrogen stable isotopes in tissues of a migratory coastal predator, summer flounder (Paralichthys dentatus). Can. J. Fish. Aquat. Sci. 67: 445-461, doi:10.1139/F09-196
Colon-Gaud, J. C., W. E. Kelso, and D. A. Rutherford. 2004. Spatial distribution of macroinvertebrates inhabiting Hydrilla and coontail beds in the Atchafalaya Basin, Louisiana. J. Aquat. Plant Manage. 42: 85-91.

Croisetiere, L., L. Hare, A. Tessier, and G. Cabana. 2009. Sulphur stable isotopes can distinguish trophic dependence on sediments and plankton in boreal lakes. Freshw. Biol. 54: 1006-1015, doi:10.1111/j.1365-2427.2008.02147.x

DAY, J. W., AND OTHERs. 2009. The impacts of pulsed reintroduction of river water on a Mississippi delta coastal basin. J. Coast. Res. 54: 225-243, doi:10.2112/SI54-015.1

FrY, B. 2002. Conservative mixing of stable isotopes across estuarine salinity gradients: A conceptual framework for monitoring watershed influences on downstream fisheries production. Estuaries 25: 264-271, doi:10.1007/BF02691313

. 2007. Coupled N, C, and S isotope measurements using a dual column GC system. Rapid Commun. Mass Spectrom. 21: $750-756$.

. 2008. Importance of open bays as nurseries for Louisiana brown shrimp. Estuaries Coasts 31: 776-789, doi:10.1007/ s12237-008-9067-2

, AND K. C. EwEl. 2003. Using stable isotopes in mangrove fisheries research. Isotopes Environ. Health Stud. 39: 191-196.

- P. L. Mumford, F. Tam, D. D. Fox, G. L. Warren, K. E. Havens, and A. L. Steinman. 1999. Trophic position and individual feeding histories of fish from Lake Okeechobee, Florida. Can. J. Fish. Aquat. Sci. 56: 590-600, doi:10.1139/f98-204

—, AND T. J. Smith, III. 2002. Stable isotope studies of red mangroves and filter feeders from the Shark River estuary, Florida. Bull. Mar. Sci. 70: 871-890.

Guelinckx, J., J. Maes, B. Geysen, And F. Ollevier. 2008. Estuarine recruitment of a marine goby reconstructed with an isotopic clock. Oecologia 157: 41-52, doi:10.1007/ s00442-008-1045-7

Hesslein, R. H., K. A. Hallard, and P. Ramlal. 1993. Replacement of sulfur, carbon, and nitrogen in tissue of growing broad whitefish (Coregonus nasus) in response to a change in diet traced by $\delta^{34} \mathrm{~S}, \delta^{13} \mathrm{C}$ and $\delta^{15} \mathrm{~N}$. Can. J. Fish. Aquat. Sci. 50: 2071-2076, doi:10.1139/f93-230

Hobson, K. A., And L. I. WassenaAr. 2008. Tracking animal migrations with stable isotopes. Elsevier Science.

Hoffman, J. C., D. A. Bronk, And J. E. Olney. 2007. Tracking nursery habitat use in the York River estuary, Virginia, by young American Shad using stable isotopes. Trans. Am. Fish. Soc. 136: 1285-1297, doi:10.1577/T06-223.1

- G. S. Peterson, A. M. Cotter, and J. R. Kelly. 2010. Using stable isotope mixing in a Great Lakes coastal tributary to determine food web linkages in young fishes. Estuaries Coasts 33: 1391-1405, doi:10.1007/s12237-010-9295-0

Lambou, V. W. 1952. Food and habitat of gar fish in the tide water of southeastern Louisiana. M.Sc. thesis. Louisiana State Univ.

Love, J. 2004. Age, growth, and reproduction of spotted gar Lepisosteus oculatus (Lepisosteidae) from the Lake Pontchartrain estuary, Louisiana. Southwest. Nat. 49: 18-23, doi:10.1894/0038-4909(2004)049<0018:AGAROS > 2.0. $\mathrm{CO} ; 2$

Minello, T. J., K. W. Able, M. P. Weinstein, and C. G. Hays. 2003. Salt marshes as nurseries for nekton: Testing hypotheses on density, growth and survival through meta-analysis. Mar. Ecol. Prog. Ser. 246: 39-59, doi:10.3354/meps246039

Phillips, D. L., AND P. M. EldRidge. 2006. Estimating the timing of diet shifts using stable isotopes. Oecologia 147: 195-203, doi:10.1007/s00442-005-0292-0 
Rees, C. E., W. J. Jenkins, And J. Monster. 1978. Sulfur isotopic composition of ocean water sulfate. Geochim. Cosmochim. Acta 42: 377-381, doi:10.1016/0016-7037(78)90268-5

Rozas, L. P., T. J. Minello, I. Munyera-Fernandez, B. Fry, and B. Wissel. 2005. Macrofaunal distributions and habitat change following winter-spring releases of freshwater into the Breton Sound Estuary, Louisiana (USA). Estuar. Coast. Shelf Sci. 65: 319-336, doi:10.1016/j.ecss.2005.05.019

Seehausen, O., and N. Bouton. 1997. Microdistribution and fluctuations in niche overlap in a rocky shore cichlid community in Lake Victoria. Ecol. Freshw. Fish 6: 161-173, doi:10.1111/j.1600-0633.1997.tb00159.x

Snedden, G. A., W. E. Kelso, and A. Rutherford. 1999. Diel and seasonal patterns of spotted gar movement and habitat use in the lower Atchafalaya River Basin, Louisiana. Trans. Am. Fish. Soc. 128: 144-154, doi:10.1577/1548-8659(1999) $128<0144$ :DASPOS $>2.0 . C O ; 2$

SOKAL, R. R., AND F. J. RohlF. 1995. Biometry: the principles and practice of statistics in biological research. 3rd ed. W. H. Freeman and Co. New York.

Swarzenski, C. M., T. W. Doyle, B. Fry, and T. G. Hargis. 2008. Biogeochemical response of organic-rich freshwater marshes in the Louisiana delta plain to chronic river water influx. Biogeochemistry 90: 49-63, doi:10.1007/s10533-008-9230-7

Tarboush, R. A., S. E. Macavoy, S. A. Macko, and V. Connaughton. 2006. Contribution of catabolic tissue replacement to the turnover of stable isotopes in Danio rerio. Can. J. Zool. 84: 1453-1460, doi:10.1139/z06-136
Thorrold, S. R., AND others. 2002. Quantifying larval retention and connectivity in marine populations with artificial and natural markers. Bull. Mar. Sci. Suppl. 70: 291-308.

Trust, B. A., AND B. Fry. 1992. Stable sulphur isotopes in plants: A review. Plant Cell Environ. 15: 1105-1110, doi:10.1111/ j.1365-3040.1992.tb01661.x

Weiss, D. J., M. Rehkaemper, M. Mclaughlin, J. Kirby, P. G. C. Campbell, T. Arnold, J. Chapman, K. Peel, and S. Gioia. 2008. Application of nontraditional stable-isotope systems to the study of sources and fate of metals in the environment. Environ. Sci. Technol. 42: 655-664, doi:10.1021/es0870855

Wells, R. J. D., J. H. Cowan, JR., And B. Fry. 2008. Feeding ecology of red snapper, Lutjanus campechanus, in the northern Gulf of Mexico. Mar. Ecol. Prog. Ser. 361: 213-225, doi: $10.3354 / \mathrm{meps} 07425$

Wissel, B., AND B. Fry. 2005. Tracing Mississippi River influences in estuarine food webs of coastal Louisiana. Oecologia 144: 659-672, doi:10.1007/s00442-005-0119-z

Associate editor: Robert E. Hecky

Received: 04 November 2010 Accepted: 02 May 2011 Amended: 13 May 2011 